\title{
ASSOCIATION OF MACRONUTRIENT INTAKE WITH PERCENTAGE OF VISCERAL FAT IN INTERNATIONAL STUDENT AT UNIVERSITAS AIRLANGGA SURABAYA
}

\author{
Salmiah Ibrahim Baswedan ${ }^{*}$, Sri Sumarmi² \\ ${ }^{1}$ Nutrition Major, Faculty of Public Health, Universitas Airlangga, Surabaya, Indonesia \\ ${ }^{2}$ Department of Nutrition, Faculty of Public Health, Universitas Airlangga, Surabaya, Indonesia \\ *E-mail: mieabaswedan@gmail.com
}

\begin{abstract}
Diets are often associated with nutritional status of a person. Good nutritional status always accompany a good diet, if the intake of food is good, then it will give a good nutritional status as well. If energy intake exceeds output energy along with low physical activity, so it can lead to a build up of fat and increase the risk of overweight and obesity. The purpose of this research was to analyze the relationship between macronutrient intake with visceral fat on foreign students Universitas Airlangga in Surabaya. This study is observational, cross-sectional research design. The research sample was 65 students, where subjects was determined by purposive with inclusion criteria that had stayed at least 6 months in Indonesia, healthy, and not on a diet. The independent variable is the level of macro nutrient adequacy. The dependent variable is the visceral fat. Data were analyzed using chi-square test with a significance level of $<0.05$ and linear regression. Results showed that there was a significant relationship between energy sufficiency level $(\mathrm{p}=$ $0.000)$ and fat $(p=0.018)$ with percentage of visceral fat. Every $1 \%$ increase in level of energy sufficiency, respondent's percentage of visceral fat will increase by 3.589 . Every additional $1 \%$ of level of fat sufficiency, percentage of visceral fat will increase by 1.712 . The higher the intake of energy and fat, there will be an increase in visceral fat. The conclusion of this study is energy and fat intake can increase visceral fat. Increasing energy sufficiency and fat will increase visceral fat as well.
\end{abstract}

Keywords: macronutrients, visceral fat, foreign student

\section{INTRODUCTION}

In Indonesia, in 2016 the Ministry of Research, Technology and Higher Education issued 6,967 study permits for foreign students (Suwignjo, 2017). The interest of foreign students in studying in Indonesia is increasing. Foreign students who apply for higher education in Indonesia range from 100-500 application letters per week which are sent to the Ministry of Research, Technology and Higher Education (Suwignjo, 2017). In Surabaya, there are several universities that have programs for foreign students such as Petra Christian University, Surabaya University (UBAYA), Ten November Institute of Technology (ITS), and Universitas Airlangga (UNAIR).

Foreign students are students who come and move from their home country to another country, bringing the values, habits, beliefs, and behavior of their country of origin (Wijaya, 2013). For some people studying in another country is a challenge in itself. Following educational programs at tertiary institutions in other countries will provide opportunities to be able to learn languages, cultures and gain meaningful life experiences for students who do (Amanah, 2015).

Switching regions can lead to changes in diet and diet. These changes are adjusted to the environment or country in which they live. Based on the results of research in several countries, if the new migrant population maintained their diet, then a person had a lower risk of disease than the native population of that country (Tobias et al., 2012).

A person's diet can be influenced by cultural factors. Cultural differences can also lead to differences in eating patterns between individuals. Cultural factors influenced a person in behaving and fulfilling basic biological needs, including food needs (Sulistyoningsih, 2011).

Previous research has shown a decrease in the amount of intake by about $\pm 20 \%$ among foreign students in Surabaya. This occured due to differences in cultural environments that made 
it difficult for foreign students to adapt and the lack of access to food. Foreign students found it difficult to find local food, besides that foreign students often skip their meals, only 1-2 times a day (Levina and Muniroh, 2018).

A person's health condition is also determined by physical activity. If the energy consumed is excessive, it is not the same as the energy expended and added with less physical activity, it can cause weight gain, increasing the risk of obesity and obesity (Mahardikawati et al., 2008). Diet has a positive relationship with obesity status. This is in line with high body fat and visceral fat deposits (Putri et al., 2017).

Visceral fat is fat in the body that accumulates in the central part of the body and wraps around the internal organs of the body. Excess visceral fat is associated with the incidence of central obesity. Central obesity is associated with an increased risk of degenerative diseases (Sugianti et al., 2009). This research was conducted to identify the intake of macro nutrients through the adequacy level of intake with the percentage of visceral fat, for foreign students at Universitas Airlangga, in Surabaya.

\section{METHODS}

This research was conducted with a crosssectional design with 65 respondents of foreign students studying at Universitas Airlangga, Surabaya. Respondents were selected using purposive sampling, with the inclusion criteria of foreign students who have lived in Indonesia for at least 6 months, were in good health and were not on a diet. Respondents who had met the inclusion criteria were contacted via email to ask about their willingness to be the respondent, their health status and diet. Email addresses were obtained from Airlangga Global Engagement (AGE) until the number of respondents was met.

The data were taken from May to June 2019. The method used when data collection was face-to-face interviews followed by measuring body visceral fat. Macro nutritional intake data were obtained from a $2 \times 24$ hour food recall questionnaire. The intake datas were analyzed using Nutrisurvey software to determine the amount of macro nutrient intake, then compared with the
Nutritional Adequacy Rate (RDA). Adequacy of macro nutrients was said to be sufficient if it meets $80 \%-110 \%$ of the RDA (WNPG, 2004).

Data on the visceral fat percentage of foreign students were obtained through direct measurement using Bioimpedance Analysis (BIA) Omron HBF375. Percentage of foreign students visceral fat compared with cut-off from Omron Healthcare. The percentage of visceral fat was categorized as normal if $\leq 9 \%$, high if $>9 \%$ to $\leq 14 \%$, and very high if $>14 \%$. Data analysis used SPSS 21 software by performing a Chi-square test to analyze the relationship between macro nutrient intake and visceral fat. The significance value used $<0.05$. To find out how much influence the intake of macro nutrients has on the percentage of visceral fat, a linear regression test was carried out on the adequacy of energy and fat with the percentage of visceral fat. This research has received approval from the Faculty of Nursing Ethics Commission on May 7, 2019 with number 1387-KEPK.

\section{RESULT AND DISCUSSION}

\section{Respondents Characteristic}

Table 1 shows that most of the respondents $(52.3 \%)$ were young adults (18-25 years). Age has a significant relationship with the incidence of central obesity (Nurrahmawati and Fatmaningrum, 2018). Most of the respondents (66.2\%) are

Table 1. Distribution of Characteristics of Foreign Students of Airlangga University, Surabaya, 2019

\begin{tabular}{lcc}
\hline \multicolumn{1}{c}{ Variable } & $\mathbf{n}$ & $\mathbf{( \% )}$ \\
\hline Age & & \\
$18-25$ years old & 34 & 52.3 \\
$26-40$ years old & 31 & 47.7 \\
Gender & & \\
Male & 24 & 37 \\
Female & 41 & 63 \\
Education & & \\
Strata 1 & 19 & 29.2 \\
Strata 2 & 43 & 66.2 \\
Strata 3 & 3 & 4.6 \\
Continent Origin & & \\
Asia & 46 & 70.8 \\
Africa & 19 & 29.2 \\
\hline
\end{tabular}


Table 2. Description of the total intake of foreign students at Airlangga University, Surabaya, 2019

\begin{tabular}{lc}
\hline \multicolumn{1}{c}{ Variable } & Total \\
\hline Energy intake (kcal) & $1781 \pm 359$ \\
Mean \pm SD & 1193 \\
Minimum & 2586 \\
Maximum & \\
Protein intake (g) & $66.15 \pm 16.33$ \\
Mean \pm SD & 38.1 \\
Minimum & 102.7 \\
Maximum & \\
Fat intake (g) & $69.7 \pm 20.7$ \\
Mean \pm SD & 28.05 \\
Minimum & 123.75 \\
Maximum & \\
Carbohydrate intake (g) & \\
Mean \pm SD & $224.56 \pm 51.93$ \\
Minimum & 121.95 \\
Maximum & 374 \\
\hline
\end{tabular}

currently pursuing a Masters degree and the largest number of respondents are from postgraduate faculties. A person's education is very influential with the level of one's individual knowledge, so that it will increase awareness of healthy living habits (Rahajeng and Tuminah, 2009).

More female respondents $(63 \%)$ than male respondents (27\%). Female gender had a significant relationship with the incidence of central obesity. Women had a 1.7 times higher risk of experiencing central obesity than men (Puspitasari, 2018). Most of the respondents came from the Asian continent (70.8\%), such as Myanmar, Malaysia, Yemen, Timor Leste, Palestine, Pakistan, Syria and Syria. In addition, there were respondents who came from the African continent, namely from Madagascar, Malagasy, Nigeria, Rwanda, Uganda, Zimbabwe, Tanzania, Ethiopia, and Kenya.

\section{Intake and Adequacy of Respondents' Macro Nutrients}

Table 2 shows that the average energy intake of foreign students was $1.781 \mathrm{kcal}$, protein was $66.15 \mathrm{~g}$, fat was $69.7 \mathrm{~g}$ and carbohydrate was 224.56 g. Table 3, shows that most $(78.5 \%$ and $81.5 \%$ ) the level of energy and carbohydrate adequacy of foreign students was in the low category. As much as $43.1 \%$ had a less adequate
Table 3. Adequacy of Macro Nutrients for Foreign Students at Airlangga University, Surabaya, 2019

\begin{tabular}{|c|c|c|}
\hline Variable & $\mathbf{n}$ & $(\%)$ \\
\hline \multicolumn{3}{|l|}{ Energy Adequacy } \\
\hline Inadequate $(<80 \% \mathrm{RDA})$ & 51 & 78.5 \\
\hline Sufficient (80-110\% RDA) & 12 & 18.5 \\
\hline Excessive (>110\% RDA) & 2 & 3.1 \\
\hline \multicolumn{3}{|l|}{ Protein Adequacy } \\
\hline Inadequate $(<80 \% \mathrm{RDA})$ & 8 & 13.3 \\
\hline Sufficient (80-110\% RDA) & 18 & 27.7 \\
\hline Excessive (>110\% RDA) & 39 & 60 \\
\hline \multicolumn{3}{|l|}{ Fat Adequacy } \\
\hline Inadequate $(<80 \% \mathrm{RDA})$ & 28 & 43.1 \\
\hline Sufficient ( $80-110 \%$ RDA) & 14 & 21.5 \\
\hline Excessive (>110\% RDA) & 23 & 35.4 \\
\hline \multicolumn{3}{|l|}{ Carbohydrate Adequacy } \\
\hline Inadequate $(<80 \% \mathrm{RDA})$ & 53 & 81.5 \\
\hline Sufficient (80-110\% RDA) & 11 & 16.9 \\
\hline Excessive (>110\% RDA) & 1 & 1.5 \\
\hline
\end{tabular}

Table 4. Foreign Student Viseral Fat Level at Airlangga University Surabaya, 2019

\begin{tabular}{lcc}
\hline \multicolumn{1}{r}{ Level } & n & $\mathbf{( \% )}$ \\
\hline Normal & 53 & 81.5 \\
High & 10 & 15.4 \\
Very high & 2 & 3.1 \\
\hline
\end{tabular}

level of fat and $60 \%$ had a more adequate level of protein

\section{Visceral Fat Level}

Table 4 shows more than $80 \%$ of foreign students had visceral fat in the normal category and less than $20 \%$ have abnormal levels. Central obesity can be seen based on the size of the waist circumference. High visceral fat affects waist circumference and can increase the risk of central obesity (Gadekar et al., 2018).

\section{Relationship between Macro Nutrient Intake and Viseral Fat}

The results of this study indicated that there was a significant relationship $(\mathrm{p}<0.05)$ between energy and fat intake and the percentage of visceral fat among foreign students at Universitas Airlangga, Surabaya. The intake of protein and carbohydrates with visceral fat in foreign students 
Table 5. Results of Chi-Square Test between Macro Nutrient Intake and Viseral Fat for Foreign Students at Universitas Airlangga, Surabaya, 2019

\begin{tabular}{lc}
\hline \multicolumn{1}{c}{ Nutrient } & p-value \\
\hline Energy & 0.000 \\
Protein & 0.261 \\
Fat & 0.018 \\
Carbohydrate & 0.188 \\
\hline
\end{tabular}

at Universitas Airlangga, Surabaya did not show a significant relationship ( $p>0.05$ ). Supported by the research of Nurrahmawati and Fatmaningrum (2018) where there was no significant relationship between carbohydrate and protein intake with the incidence of central obesity.

Based on the results of the linear regression test above, the regression function for energy adequacy was $\mathrm{Y}=0.898+3.589 \mathrm{X}$ and for fat adequacy was $\mathrm{Y}=2.038+1.712 \mathrm{X}$. Each additional $1 \%$ level of energy sufficiency, the percentage of visceral fat of the respondent will increase by 3.589. For every $1 \%$ increase in the adequacy level of fat, the percentage of visceral fat will increase by 1.712 . The higher the energy and fat intake, the increase in visceral fat will occur.

Another study conducted by Sholuhiyah (2018) showed a significant relationship between the level of energy adequacy and visceral fat $(\mathrm{p}=$ 0.037). High levels of energy sufficiency will be followed by high visceral fat. In contrast to Sofa's research (2018) where there was no significant relationship between visceral fat and food intake.

The size of the waist circumference can be affected by the level of visceral fat. The risk of experiencing central obesity can increase due to the higher percentage of visceral fat (Gadekar et., 2018).

Central obesity can occur when more energy in the form of food enters the body than the energy needed or used and will be stored in the form of fat. Excess fat will be accumulated in the abdominal adipose tissue in the form of triglycerides. High calorie intake, lifestyle modernization, and low physical activity are other factors that cause central obesity (Pahlevi, 2012).

Central obesity is associated with an increased risk of degenerative diseases (Sugianti et al., 2009). Degenerative diseases in question such as cardiovascular disease, dyslipidemia, diabetes mellitus II, hypertension, and insulin resistance.

\section{CONCLUSION}

Energy and fat intake were significantly associated with visceral glue. The higher the intake of energy and fat that is not used by the body, it will be stored and accumulated into fat and the higher the level of visceral fat. The intake of carbohydrates with protein was not significantly associated with visceral fat. The greater the energy intake and fat accumulated, the visceral fat will increase.

\section{REFERENCES}

Amanah, S. (2015) Pola komunikasi dan proses akulturasi mahasiswa asing di STAIN Kediri, Realita, 13(1), 54-64. Retrieved from http:// jurnal.iainkediri.ac.id/index.php/realita/article/ view/52.

Gadekar, T. (2018) Correlation of visceral body fat with waist-hip ratio, waist circumference and body mass index in healthy adults: A cross sectional study, Medical Journal Armed Forces India. Director General, Armed Forces Medical Services, 1-6. doi: 10.1016/j. mjafi.2017.12.001.

Levina, A. \& Muniroh, L. (2018) Perbedaan asupan makronutrien mahasiswa asing sebelum dan saat tinggal di Surabaya, Indonesia, Gizi Indonesia, 41(2), pp. 97-104. Retrieved from https:// ejournal.persagi.org/index.php/Gizi_Indon/ article/view/291.

Mahardikawati, K., Venny, A. \& Roosita (2008) Aktivitas fisik, asupan energi dan status gizi wanita pemetik teh di PTPN VIII Bandung, Jawa Barat, Jurnal Gizi dan Pangan, 3(2), 79-85. doi: 10.25182/jgp.2008.3.2.79-85

Nurrahmawati, F. \& Fatmaningrum, W. (2018) Hubungan usia, stres, dan asupan zat gizi makro dengan kejadian obesitas abdominal pada ibu rumah tangga di Kelurahan Sidotopo, Surabaya. Amerta, 2(3), 254-264. doi: 10.20473/amnt. v2.i3.2018.254-264.

Pahlevi, A.E. (2012) Determinan status gizi pada siswa sekolah dasar, KESMAS - Jurnal Kesehatan Masyarakat, 7(2), 122-126. doi: 10.15294/kemas.v7i2.1770.

Puspitasari, N. (2018) Kejadian obesitas sentral pada usia dewasa, HIGEIA (Journal of Public 
Health Research and Development), 2(2), 249-259. doi: 10.15294/higeia.v2i2.21112.

Putri, V.R., Angkasa, D. \& Nuzrina, R. (2017)

'Konsumsi fast food, soft drink, aktivitas fisik, dan kejadian overweight siswa sekolah dasar di Jakarta', Indonesian Journal of Human Nutrition, 4(1), 47-57. doi: 10.21776/ ub.ijhn.2017.004.01.5.

Rahajeng, E. \& Tuminah, S. (2009) Prevalensi hipertensi dan determinannya di Indonesia, Majalah Kedokteran Indonesia, 59, 580-587.

Regev-Tobias, H. (2012) Dietary acculturation and increasing rates of obesity in Ethiopian women living in Israel, Nutrition. 28(1), 30-34. doi: 10.1016/j.nut.2011.02.010.

Sholuhiyah, Z. (2018) Hubungan tingkat kecukupan energi dan zat gizi, aktivitas fisik, dan status gizi dengan komposisi tubuh pegawai Smkn 13 Jakarta. Institut Pertanian Bogor.
Sofa, I.M. (2018) Kejadian obesitas , obesitas sentral, dan kelebihan lemak viseral pada lansia wanita, Amerta Nutrition, 2(3), 228-236. doi: 10.20473/amnt.v2.i3.2018.228-236.

Sugianti, E., Hardinsyah \& Afriansyah, N. (2009) Faktor risiko obesitas sentral, Gizi Indonesia, 32(2), 105-116.

Suwignjo, P. (2017) Perguruan Tinggi Indonesia Diminati Mahasiswa Asing. Jakarta. Retrieved from https://www.ristekdikti.go.id/siaranpers/perguruan-tinggi-indonesia-diminatimahasiswa-asing- $2 /$.

Wijaya, R. (2013) Anxiety uncertainty management mahasiswi inholland program studi manajemen bisnis internasional, E-Komunikasi, 1(1). Retrieved from http://publication.petra.ac.id/ index.php/ilmu-komunikasi/article/view/127. 